\title{
From the Editor
}

\section{Musical links to medicine}

Many hospitals can trace their roots to the 18th century when voluntary hospitals were first founded in the provinces. The earliest were Winchester (1736) and Bristol (1737). John Ash, a leading physician, locally proposed that a general hospital should be established near the town of Birmingham in 1765. A shortage of money curtailed the building programme and the General Hospital Birmingham was formally

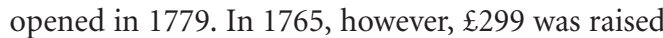
for hospital funds from a music festival. This was formalised in 1768 and over the next 150 years, until the first world war, more than $£ 160,000$ was raised by the Triennial Music Festivals. Felix Mendelssohn visited several times and his great oratorio Elijah premiered at the festival in 1846, while Edward Elgar conducted the first performance of The Dream of Gerontius at the festival in 1900.

The hospital fundraising musical link was revived in 1984 when for seven years the City of Birmingham Symphony Orchestra played an annual concert to boost the Bicentenary Research Fund. Highlights included Simon Rattle, the conductor, who, with his family and members of the orchestra, would join the staff for supper at the hospital. The consultant staff responded by providing prompt medical services for any member of the orchestra, which I coordinated and which continues to this day.

When Professor Ian McDonald, the neurologist, editorial board member and musicophile, called into the editorial office to wish the new incumbent well, it was no surprise that music was an early topic of conversation. Over several meetings we discussed the outline of a series for the Journal concerned with medicine, music and the mind. Early on in the discussions Ian invited Jason Warren to join him as co-editor. The duo was instrumental in suggesting and assembling a fascinating series of essays by distinguished contributors.

Following Ian's untimely death in 2006, Jason kindly assumed the role of editor and brought the series to fruition. The series is dedicated to Ian's memory and his wonderful capacity to develop constructive and happy friendships which have brought so much pleasure to so many. In this issue, Jason introduces the series and contributes the first essay. We are greatly in his debt.

ROBERT ALLAN

Members of the Editorial Board

Professor Robert Allan (Editor)
Paul Belcher
Professor Morris J Brown
Dr Rodger Charlton
Dr Pamela W Ewan
Dr lan Forgacs

\author{
Dr Paul Grant \\ Professor Humphrey Hodgson \\ Professor Shirley Hodgson \\ Professor Brian Hurwitz \\ Professor Parveen Kumar \\ Professor David Lomas
}

Professor Martin McKee

Professor John Saunders

Dr lan Starke

Professor David Warrell

Professor Adam Zeman 